\title{
Cross-reacting material in genetic variants of haemophilia B
}

\author{
DOMINIQUE MEYER, ETHEL BIDWELL, AND MARIE JOSÉ LARRIEU
}

From the Coagulation Department, Institut de Pathologie Cellulaire, Hôpital Bicêtre, Paris, France, and the Churchill Hospital, Oxford

SYNOPSIS Cross-reacting factor IX material (CRM) was immunologically detected in the plasma of 38 normal individuals and 21 out of 22 haemophilia B patients using a rabbit antibody to factor IX. The same reacting material was detected in only nine of these patients using a human antibody. These results indicate that the plasma of the majority of haemophilia B patients contains a protein-lacking biological activity but having antigenic determinants in common with normal factor IX.

Genetic variants of haemophilia A and B (factor VIII and IX deficiencies) have been recently demonstrated by the ability or inability of the patient's plasma to neutralize specific human antibodies against factor VIII or IX (Roberts, Gross, Webster, and Dejanov, 1966; Denson, Biggs, and Mannucci, 1968; Hoyer and Breckenridge, 1968; Roberts, Grizzle, McLester, and Penick, 1968; Feinstein, Chong, Kasper, and Rapaport, 1969; Denson, Biggs, Haddon, Borrett, and Cobb, 1969; Brown, Hougie, and Roberts, 1970; Meyer, Dray, and Larrieu, 1970; Hoyer and Breckenridge, 1970; Meyer and Larrieu, 1971). In most patients (haemophilia $\mathrm{A}^{-}$or $\mathrm{B}^{-}$) immunological cross-reacting material was absent, while in 10 to $15 \%$ of them an inactive protein could be demonstrated (haemophilia $\mathbf{A}^{+}$or $\mathbf{B}^{+}$). However, conflicting data were obtained in haemophilia $\mathbf{A}$ when using factor VIII antibodies raised in different species (rabbit, goat) by immunization with partially purified factor VIII. Depending on the reactivity of the various antibodies, inactive cross-reacting material could be demonstrated in a highly variable percentage of haemophilia A patients: $100 \%$ (Zimmerman, Ratnoff, and Powell, 1971; Stites, Hershgold, Perlman, and Fudenberg, 1971; Meyer, Lavergne, Larrieu, and Josso, 1972), $90 \%$ (Bennett and Huehns, 1970), or around $15 \%$ (Denson et al, 1969; Gralnick, Abrell, and Bagley, 1971). The present study demonstrates a similar discrepancy when the reactivity of different haemophilia B plasmas was compared with two types of factor IX antibodies, namely, a human inhibitor which occurred in a transfused haemophilia B patient, and rabbit antibodies raised by immunization with a partially purified antigen.

Received for publication 18 November 1971 .

\section{Materials and Methods}

The factor IX concentrate used as a source of antigen was a sample from a batch of human material (RD40) prepared at the Oxford Haemophilia Centre by batch adsorption on DEAE-cellulose followed by displacement elution in a column (Dike, Bidwell, and Rizza, 1972). This concentrate contained $62 \mathrm{U} / \mathrm{ml}$ factor IX, $50 \mathrm{U} / \mathrm{ml}$ factor II, $44 \mathrm{U} / \mathrm{ml}$ factor $\mathrm{X}$, and a very low concentration of factor VII $(1.7 \mathrm{U} / \mathrm{ml})$. The protein concentration was $10 \mathrm{mg} / \mathrm{ml}$ and the purification with respect to factor IX was 400 -fold.

Rabbit antisera were obtained by injection of equal parts of factor IX concentrate and complete Freund's adjuvant. Three injections ( $6 \mathrm{mg}$ protein) were given at intervals of eight days, the first one in the popliteal lymph node and subsequent ones in foot pads. Blood was drawn 10 days after the last injection, and allowed to clot in glass tubes, which were kept at $37^{\circ} \mathrm{C}$ for six hours and at $4^{\circ} \mathrm{C}$ for -12 hours. Serum was obtained by centrifugation at $5000 \mathrm{~g}$ for $15 \mathrm{~min}$, oxalated, adsorbed with barium carbonate $(40 \mathrm{mg} / \mathrm{ml})$, and heated at $56^{\circ} \mathrm{C}$ for 30 minutes. The antibody titres (Denson, 1967) were $5 \mathrm{U} / \mathrm{ml}$ and $18 \mathrm{U} / \mathrm{ml}(1 \mathrm{U}$ was defined as the amount of serum destroying $75 \%$ factor IX after incubation at $37^{\circ} \mathrm{C}$ for $15 \mathrm{~min}$ ). The anti-factor II and antifactor $\mathrm{X}$ antibody titres were $<2 \mathrm{U} / \mathrm{ml}$. These antibodies were not specific for factor IX, as by immunodiffusion four lines of precipitation were shown against normal plasma or factor IX concentrate.

Human factor IX antibody was a specific inhibitor which appeared in a haemophilia B patient after multiple transfusions. The antibody titre was $15 \mathrm{U} / \mathrm{ml}$. 
Factor IX activity was measured by a one-stage assay (Langdell, Wagner, and Brinkhous, 1953), and prothrombin time with human and ox-brain thromboplastin (Thrombotest) as previously described (Meyer and Larrieu, 1971).

Inhibitor-neutralizing activity was measured by a modified two-stage procedure (Denson et al, 1969). In the first step, $0.4 \mathrm{ml}$ of normal or test plasma was incubated at $37^{\circ} \mathrm{C}$ for $15 \mathrm{~min}$ with $0.1 \mathrm{ml}$ of an appropriate dilution of human or rabbit antibody. In the second step, $0.2 \mathrm{ml}$ of normal plasma was added to an equal volume of the first mixture. After a second incubation at $37^{\circ} \mathrm{C}$ for $15 \mathrm{~min}$ residual factor IX was measured by a one-stage assay. Results were expressed as units of neutralized inhibitor.

\section{Results}

INHIBITOR-NEUTRALIZING ACTIVITY IN CONTROL PLASMAS

The specificity of the factor IX assays ensures the specificity of the inhibitor-neutralizing technique for the antigenic determinants of factor IX. Other coagulation factor antibodies, such as anti-factor VIII (from human or rabbit origin) or rabbit antihuman factor II, ${ }^{1}$ tested in the same system, did not interfere with the final assay of factor IX after the two incubations.

Inhibitor-neutralizing activity was measured in normal plasma (38 experiments): it varied from 0.85 to 1.07 unit (mean $1.03 \pm 0.07$ unit) when using

${ }^{1}$ Kindly provided by J. M. Lavergne and F. Josso, Hôpital Necker, Paris.

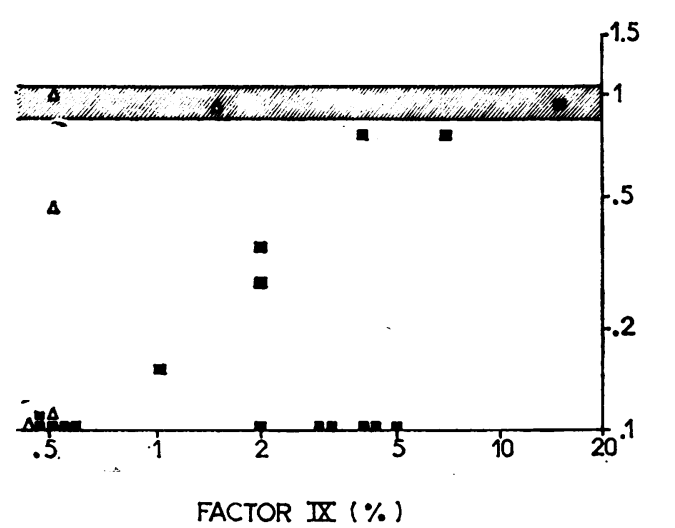

Fig. 1 Inhibitor-neutralizing activity in 22 cases of haemophilia $B$ (human factor IX ithibitor)

Haemophilia B

$\therefore$ Haemophilia B.r human antibody (Fig. 1), and from 0.85 to 1.25 unit (mean $0.92 \pm 0.05$ unit) when using antihuman factor IX antiserum (Fig. 2). Cross-reacting material $\overrightarrow{\bar{\omega}}$ was present in normal serum as well as in the plasma of coagulation deficiencies other than factor IX. It was lacking in aluminium hydroxide or barium sulphate-adsorbed plasma or serum, the results being the same as those with citrated saline.

INHIBITOR-NEUTRALIZING ACTIVITY IN

PATIENTS WITH HAEMOPHILIA B

Twenty-two haemophilia B patients were tested in ${ }_{\sigma}$ the same way using both human and rabbit anti- $\overline{0}$ bodies.

\section{Human antibody}

Plasma samples from 13 haemophilia B patients $\stackrel{\vec{\omega}}{\vec{\omega}}$ failed to neutralize the human antibody. These 0 patients were classified as haemophilia $\mathrm{B}^{-}$. Five plasmas contained an amount of cross-reacting $\vec{z}$ material identical to that in normal plasma, and four showed intermediate results (Fig. 1). These nine $\vec{\varphi}$ patients were classified as haemophilia $\mathrm{B}^{+}$.

\section{Rabbit antiserum}

The capacity of the same plasmas to neutralize the rabbit antihuman factor IX antibodies appeared entirely different. Only one patient out of the $22 \%$ tested lacked immunologically detectable cross- $\varrho$ reacting material (Fig. 2). This patient had a moder- $\overrightarrow{\vec{O}}$ ate form of haemophilia B (factor IX activity $4 \%$ ). 3 In 14 patients plasma inhibitor neutralizing activity varied from 0.65 to 1.1 unit, ie, within the normal

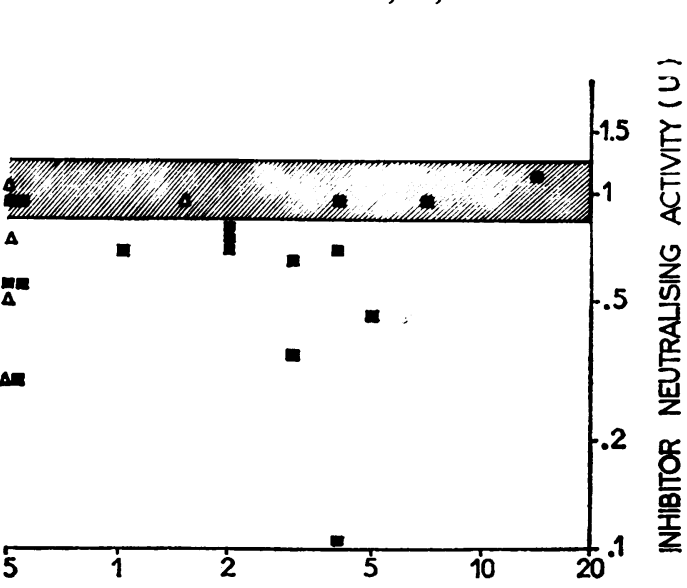

FACTOR IX $(\%)$

Fig. 2 Inhibitor-neutralizing activity in 22 cases haemophilia B (rabbit factor IX antiserum).

Wormal range. 
range, and seven patients had intermediate values, from 0.30 to 0.55 unit. The same results were observed using two different rabbit antisera. No correlation was found between the level of active factor IX and the amount of factor IX antigen.

\section{OX BRAIN CLOTTING TIME IN PATIENTS WITH} HAEMOPHILIA B

In five of the 22 patients tested, the Thrombotest time (or clotting time in the presence of ox-brain thromboplastin) was prolonged on repeated testing $(62-85 \mathrm{sec})$ while the clotting time was normal in the presence of human brain thromboplastin. These patients were classified as haemophilia $\mathbf{B}_{\mathbf{M}}$ (Hougie and Twomey, 1967). Cross-reacting material was present in three of these patients when tested by human antibody, and in all five when tested with rabbit antibody (Table I).

\begin{tabular}{lll}
\hline \multirow{2}{*}{$\begin{array}{l}\text { Factor IX Activity } \\
\%\end{array}$} & \multicolumn{2}{l}{ Factor IX Antigen (INA Units) } \\
\cline { 2 - 3 } & Human Antibody & Rabbit Antibody \\
\hline$<1$ & 0 & 0.50 \\
$<1$ & 0 & 0.30 \\
$<1$ & 0.46 & 1.05 \\
$<1$ & 1.05 & 0.95 \\
1.5 & 0.92 & 0.95 \\
Control (mean) & 0.92 & 1.03 \\
\hline
\end{tabular}

Table I Inhibitor-neutralizing activity in haemophilia $B_{M}$ (five patients) (comparison of two types of antibodies)

RELATIONSHIP BETWEEN FACTOR IX VARIANTS Among the 22 patients with haemophilia $B$ we studied with both methods, four groups could be distinguished when using factor IX human antibody (Table II). In the first group (11 patients with a severe or a moderate form of the disease), the Thrombotest was normal and antigenic activity lacking. In the second group (six patients with moderate haemophilia), the Thrombotest was normal, and the plasma

\begin{tabular}{|c|c|c|c|}
\hline \multirow[t]{2}{*}{ Antibody } & \multirow[t]{2}{*}{ No. of Cases } & \multicolumn{2}{|c|}{ Haemophilia } \\
\hline & & $B_{\mathbf{M}}$ & $B^{+}$ \\
\hline \multicolumn{4}{|l|}{ Human } \\
\hline I & 11 & 一 & - \\
\hline II & 6 & - & + \\
\hline $\begin{array}{l}\text { III } \\
\text { IV }\end{array}$ & $\begin{array}{l}2 \\
3\end{array}$ & + & $\overline{+}$ \\
\hline \multicolumn{4}{|l|}{ Rabbit } \\
\hline I & 1 & - & - \\
\hline II & 16 & - & + \\
\hline III & 0 & + & - \\
\hline IV & 5 & + & + \\
\hline
\end{tabular}

Table II Classification of patients with haemophilia $B$ according to the results of Thrombotest and inhibitorneutralizing activity contained factor IX antigenic determinants. Conversely in the third group (two patients with severe haemophilia) the Thrombotest was prolonged but antigenic material lacking. In the fourth group, three patients had both haemophilia $\mathbf{B}_{\mathbf{M}}$ and $\mathbf{B}^{+}$. The groups were entirely different when employing rabbit antibody (Table II). Twenty-one patients were classified in groups II and IV (haemophilia $\mathrm{B}^{+}$), and one in group $\mathrm{I}$.

\section{Discussion}

A large heterogeneity with a wide spectrum of variants had already been demonstrated in haemophilia B when using a human factor IX inhibitor. Two different molecular abnormalities have been recently described: haemophilia $\mathbf{B}_{\mathbf{M}}$ (Hougie and Twomey, 1967) and haemophilia $\mathrm{B}^{+}$(Denson et al, 1968; Roberts et al, 1968; Meyer and Larrieu, 1971). Our results, obtained with factor IX antisera raised in rabbits, suggest that in nearly all haemophilia B patients (21 out of 22), the lack of factor IXactivity is due to the synthesis of an inactive protein, having antigenic determinants in common with normal factor IX. These results are in agreement with those obtained with factor VIII antibodies raised in rabbits (Zimmerman et al, 1971; Bennett and Huehns, 1970; Stites et al, 1971; Meyer et al, 1972). The large discrepancy between the results obtained with the two types of factor IX antibodies in haemophilia B patients suggests that more than one antigenic site is involved on factor IX protein. Factor IX antisera raised in rabbits probably contain some antibodies which react with antigenic determinants present on the factor IX molecule, other than those responsible for the development of antibody(ies) in some haemophilia B patients after multiple transfusions.

This work was supported by a grant from INSERM. We wish to thank G. W. R. Dike (Oxford Haemophilia Centre) for providing factor IX concentrate. The technical help of B. Obert is gratefully acknowledged.

\section{References}

Bennett, E., and Huehns, E. R. (1970). Immunological differentiation of three types of haemophilia and identification of some female carriers. Lancet, 2, 956-958.

Brown, P. E., Hougie, C., and Roberts, H. R. (1970). The genetic heterogeneity of haemophilia B. New Engl. J. Med., 283, 61-64.

Denson, K. W. E. (1967). The Use of Antibodies in the Study of Blood Coagulation. vol. 1, p. 244. Blackwell, Oxford and Edinburgh.

Denson, K. W. E., Biggs, R., and Mannucci, P. M. (1968). An investigation of three patients with Christmas disease due to an abnormal type of Factor IX. J. clin. Path., 21, 160-165.

Denson, K. W. E., Biggs, R., Haddon, M. E., Borrett, R., and Cobb, K. (1969). Two types of haemophilia $\left(A^{+}\right.$and $\left.A^{-}\right)$: a study of 48 cases. Brit. J. Haemat., 17, 163-171.

Dike, G. W. R., Bidwell, E., and Rizza, C. R. (1972). The preparation 
and clinical use of a new concentrate containing Factor IX, prothrombin, and Factor X. Brit. J. Haemat., in press.

Feinstein, D., Chong, M. N. Y., Kasper, C. K., and Rapaport, S. I. (1969). Haemophilia A: polymorphism detectable by a Factor VIII antibody. Science, 163, 1071-1072.

Gralnick, H. R., Abrell, E., and Bagley, J. (1971). Immunological studies of factor VIII (anti-haemophiliac globulin) in haemophilia A. Nature [New Biol.], 230, 16-17.

Hougie, C., and Twomey, J. J. (1967). Haemophilia BM: a new type of Factor IX deficiency. Lancet, 1, 698-700.

Hoyer, L. W., and Breckenridge, R. T. (1968). Immunological studies of antihemophilic factor (AHF, factor-VIII): cross-reacting material in a genetic variant of haemophilia A. Blood, 32, 962-971.

Hoyer, L. W., and Breckenridge, T. R. (1970). Immunologic studies of antihemophilic factor (AHF, factor-VIII). II. Properties of cross-reacting material. Blood, 35, 809-820.

Langdell, R. D., Wagner, R. H., and Brinkhous, K. M. (1953), Effect of antihemophilic factor on one stage clotting tests. J. Lab clin. Med., 41, 637-647.

Meyer, D., Dray, L., and Larrieu, M. J. (1970). Hémophilie. Les variants des Facteurs VIII et IX. Nouv. Rev. franc. Hémat., 10, 619-626.
Meyer, D., and Larrieu, M. J. (1971). Factor VIII and IX variants. Relationship between haemophilia $\mathbf{B}_{\mathrm{M}}$ and haemophilia $\mathbf{B}^{+}$.으 Europ. J. clin. Invest., 1, 425-431.

Meyer, D., Lavergne, J. M., Larrieu, M. J., and Josse, F. (1972). Cross-reacting material in congenital factor VIII deficiencies $\stackrel{\oplus}{+}$ (haemophilia A and von Willebrand's disease). Thrombos. Res., in press.

Roberts, H. R., Grizzle, J. E., McLester, W. D., and Penick, G. D. (1968). Genetic variants of Hemophilia B: detection by means $\frac{\bar{\sigma}}{\sigma}$ of a specific PTC inhibitor. J. clin. Invest., 47, 360-365.

Roberts, H. R., Gross, G. P., Webster, W. P., Dejanov, I. I., and Penick, G. D. (1966). Acquired inhibitors of plasma Factor IX.ص A study of their induction, properties and neutralisation. Amer. J. med. Sci., 251, 43-50 and 56.

Stites, D. P., Hershgold, E. J., Perlman, J. D., and Fudenberg, H. H. (1971). Factor VIII detection by hemagglutination inhibition: $\overrightarrow{\vec{\omega}}$ hemophilia $A$ and Von Willebrand's disease. Science, 171, 196-197.

Zimmerman, T. S., Ratnoff, O. D., and Powell, A. E. (1971). Immuno-응 logic differentiation of classic hemophilia (factor VIIIN deficiency) and von Willebrand's disease. J. clin. Invest., 50, 244-G 254.

\section{Reports and Bulletins prepared by the Association of Clinical Biochemists $\stackrel{\circ}{\triangle}$}

The following reports and bulletins are published by the Association of Clinical Biochemists. They may be obtained from The Administrative Office, Association of Clinical Biochemists, 7 Warwick Court, Holborn, London, WC1R 5DP. $\overrightarrow{0}$ The prices include postage, but air mail will be charged extra. Overseas readers should remit by British Postal or Money Order. If this is not possible the equivalent of $50 \mathrm{p}$ is the minimum amount that can be accepted.

\section{SCIENTIFIC REPORTS}

3 Automatic Dispensing Pipettes. An assessment of 35 commercial instruments 1967 P. M. G. BROUGHTON, A. H. GOWENLOCK, G. M. WIDDOWSON, and K. A. AHLQUIST $85 p(\$ 2)$

4 An Evaluation of five Commercial Flame Photometers suitable for the Simultaneous Determination of Sodium and Potassium March 1970 P. M. G. BROUGHTON and J. B. DAWSON $85 \mathrm{p}(\$ 2)$

\section{SCIENTIFIC REVIEWS}

1 The Assessment of Thyroid Function March 1971 F. V. FLYNN and J. R. HOBBS $62 \frac{1}{2} \mathrm{p}(\$ 1.50)$

2 Renal Function Tests Suitable for Clinical Practice January 1972 F. L. MITCHELL, N. VEALL, and R. W. E. WATTS $62 \frac{1}{2} \mathrm{p}(\$ 1.50)$

\section{TECHNICAL BULLETINS}

9 Determination of Urea by AutoAnalyzer November

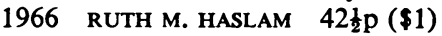

11 Determination of Serum Albumin by AutoAnalyzer using Bromocresol Green October 1967 B. E. NORTHAM and G. M. WIDDOwSON $42 \frac{1}{2} \mathrm{p}(\$ 1)$

13 An Assessment of the Technicon Type II Sampler Unit March 1968 B. C. GRAY and G. K. McGOWAN $42 \frac{1}{2} p(\$ 1)$

14 Atomic Absorption Spectroscopy. An outline of its principles and a guide to the selection of instruments May 1968 J. B. DAWSON and P. M. G. BROUGHTON $42 \frac{1}{2} p(\$ 1)$
15 A Guide to Automatic Pipettes (2nd edition) June 1968 P. M. G. BROUGHTON $42 \frac{1}{2} p(\$ 1)$

16 A Guide to Automation in Clinical Chemistry May $\stackrel{2}{\circ}$ 1969 P. M. G. BROUGHTON $62 \frac{1}{2} \mathrm{p}(\$ 1.50)$

17 Flame Photometers (2nd edition) 1969 $62 \frac{1}{2} \mathrm{p}(\$ 1.50)$

18 Control Solutions for Clinical Biochemistry (4th edition) March 1970 P. M. G. BROUGHTON $62 \frac{1}{2} \mathrm{p}$ 응 $(\$ 1.50)$

19 Spectrophotometers. A comparative list of low-priced instruments readily available in Britain May 1970윽 C. E. WILDE and P. SEWELL $62 \frac{1}{2} \mathrm{p}(\$ 1.50)$

20 Quantities and Units in Clinical Biochemistry June 1970 P. M. G. BROUGHTON $62 \frac{1}{2} \mathrm{p}(\$ 1.50)$ More than 30 copies in units of 10 at $20 \mathrm{p}$

21 Filter Fluorimeters: A comparative list of 18 instruments September 1970 H. BRAUNSBERG and s. S. BROWN $62 \frac{1}{2} \mathrm{p}(\$ 1.50)$

22 Bilirubin standards and the Determination of Bilirubin by Manual and Technicon AutoAnalyzer Methods. January 1971 BARBARA BILLING, RUTH HASLAM, and $\stackrel{\oplus}{\oplus}$ N. WALD $62 \frac{1}{2} \mathrm{p}(\$ 1.50)$

23 Interchangeable Cells for Spectrophotometers and Fluorimeters September 1971 E. S. BROWN and A. H. GOWENLOCK $62 \frac{1}{2} \mathrm{p}(\$ 1.50)$

24 Simple Tests to Detect Poisons March 1972 B. w. MEADE $t \quad l . \quad 62 \frac{1}{2}(\$ 1.50)$ 